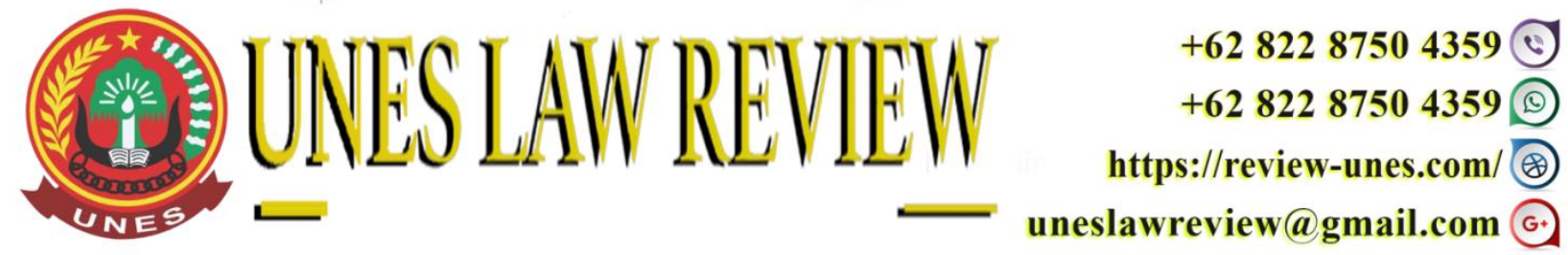

DOI: https://doi.org/10.31933/unesrev.v3i3

Diterima: 07/04/2021, Diperbaiki: 19/04/2021, Diterbitkan: 20/04/2021

\title{
PROBLEMATIKA HUKUM PENGELOLAAN SAMPAH DI KOTA PEKANBARU
}

\author{
Silm Oktapani ${ }^{1}$, Ardiansah $^{2}$ \\ 1), 2) Program Studi Ilmu Hukum, Universitas Lancang Kuning, Pekanbaru, Riau Indonesia \\ Email: silm@unilak.ac.id \\ Corresponding Author: Silm Oktapani
}

\section{ABSTRACT}

The existence of garbage is a very serious matter in Pekanbaru City, with the increasing population resulting in an increase in the amount of waste produced every day. It is a concern for the Pekanbaru City Government to be able to overcome the problems that are increasing day by day. Regional Regulation Number 8 of 2014 concerning waste management is the basis for the implementation of the waste management policy. This study aims to see what are the legal problems for waste management in Pekanbaru City. The sociological law method is a method in this research to see how the law enforcement process is and how the law is enforced in society. The difficulty of changing people's habits in sorting organic and inorganic waste has made the waste management process unable to run optimally, and the lack of waste transport fleets is also one of the problems in waste management. The importance of the optimal role of the Pekanbaru City Government to the waste bank as an organization that helps the Pekanbaru City Government in its efforts to save money.

Keywords: Management, Garbage, Pekanbaru

\begin{abstract}
ABSTRAK
Keberadaan sampah merupakan suatu hal yang sangat serius dialami Kota Pekanbaru, dengan bertambahnya penduduk mengakibatkan bertambahnya jumlah pasokan sampah yang dihasilkan setiap harinya. Menjadi perhatian bagi Pemerintah Kota Pekanbaru untuk dapat mengatasi adanya permasalahan sampah yang semakin hari semakin meningkat. Peraturan Daerah Nomor 8 Tahun 2014 Tentang Pengelolaan sampah menjadi dasar berlakunya kebijakan mengenai pengelolaan sampah. Penelitian ini bertujuan untuk mengetahui apa saja yang menjadi permasalahan hukum pengeloaan sampah di Kota Pekanbaru. Metode Hukum Sosiologis menjadi metode dalam penelitian ini untuk mengetahui bagaimana proses penegakan hukum dan bagaimana dilaksakannya hukum tersebut didalam masyarakat. Sulitnya merubah kebiasaan masyarakat untuk memilah sampah organik dan anorganik menjadikan proses pengelolaan sampah ini tidak dapat berjalan maksimal, serta armada pengangkut sampah yang kurang juga
\end{abstract}


menjadi salah satu permasalahan dalam hal pengelolaan sampah. Pentingnya peran Pemerintah Kota Pekanbaru secara optimal kepada bank sampah selaku organisasi yang membantu Pemerintah Kota Pekanbaru dalam upaya pengurangan sampah.

Kata Kunci: Pengelolaan, Sampah, Pekanbaru

\section{PENDAHULUAN}

Permasalahan sampah adalah permasalah yang umum dan merupakan fenomena universal diberbagai belahan negara di dunia. ${ }^{1}$ Sampah merupakan hasil buangan yang dihasilkan dari suatu proses produksi dari industri maupun domestik (rumah tangga). ${ }^{2}$ Sampah merupakan konsekuensi dari adanya aktivitas kehidupan manusia, ini merupakan salah satu permasalahan serius yang dialami kota-kota besar di Indonesia.

Bertambahnya jumlah penduduk yang meningkat disetiap tahunnya, serta perkembangan industri yang juga ikut meningkat dibarengi dengan meningkatnya sampah industri dan sampah domestik yang dihasilkan oleh penduduk yang semakin membebani tanah, udara dan sungai yang mengalir dalam areal perkotaan. ${ }^{3}$

Sampah dapat berpengaruh negatif terhadap lingkungan hidup dan masyarakat sehingga pengelolaan sampah sangat diperlukan. Polusi dan pencemaran dapat diakibatkan oleh sampah, mulai dari polusi air, udara dan tanah. ${ }^{4}$

Hal-hal yang dapat mengakbatkan timbulnya sampah adalah (1) pertumbuhan jumlah penduduk yang semakin banyakberpengaruh kepada sampah yang dihasilkan, (2) dengan semakn meningkatnya keberadaan sosial ekonomi masyarakat tentunya akan meningkatkan volume perkapita sampah yang dihasilkan, (3) kemajuan teknologi dalam penggunaan bahan baku yang tidak bisa diurai dengan jenis yang semakin beragam. ${ }^{5}$

Berdasarkan Undang-Undang No.18 Tahun 2008 Tentang Pengelolaan Sampah yang mengatur mengenai kepastian hukum, kejelasan tugas dan wewenang Pemerintah daerah serta hak dan kewajiban masyarakat/pelaku usaha sehingga pengelolaan sampah dapat berjalan secara proporsional. Undang-undang No.18 tahun 2008 ini menekankan dalam hal prioritas utama yang harus dilakukan oleh semua pihak, bagaimana agar sampah dapat semaksimal mungkin dikurangi. ${ }^{6}$

${ }^{1}$ Roza Linda, 'Pemberdayaan Ekonomi Kreatif Melalui Daur Ulang Sampah Plastik (studi kasus bank sampah berlian kelurahan tangkerang labuai)', Jurnal Al-Iqtishad, Vol. 1 No.12, (2016), hlm. 1.

${ }^{2}$ Imah Luluk Kusminah, 'Penyuluhan 4R (Reduce, Reuse, Recycle, Replace) Dan Kegunan Bank Sampah Sebagai Langkah Menciptakan Lingkungan Yang Bersih Dan Ekonomis Di Desa Mojowuku Kabupaten Gresik', Jurnal Pengabdian Masyarakat LPPM Untag Surabaya, Vol. 3 No.1, (2018), hlm. 22.

${ }^{3}$ Irienda Rielasari, 'Pengelolaan Sampah Kota Pekanbaru', JOM FISIP, Vol. 5 No.1, (2018), hlm. 2.

${ }^{4}$ Yudi Anugrah Purwadi, 'Implementasi Peraturan Daerah Kota Pekanbaru Nomor 08 Tahun 2014 Tentang Pengelolaan Sampah (Studi Tentang Masyarakat Peduli Sampah)', JOM FISIP, Vol. 4 No. 2, (2017), hlm. 2.

${ }^{5}$ Hadnan Bachtiar, Imam Hanafi dan Mochamad Rozikin, 'Pengembangan Bank Sampah Sebagai Bentuk Partisipasi Masyarakat Dalam Pengolahan Sampah (studi pada koperasi bank sampah malang)', Jurnal Administrasi Publik (JAP), Vol. 3 No.1, hlm.129.

${ }^{6}$ Dilva Ramdhan, 'Kebijakan Daerah Pemerintah Kota Pekanbaru Dalam Pengelolaan Sampah Denga Konsep 3r Tahun 2017', JOM FISIP, Vol.6 No.11, (2019), hlm. 2. 
Salah satu Tempat Pembuangan Akhir (TPA) di Kota Pekanbaru berlokasi di Muara Fajar yang setiap harinya mendapat kiriman sebanyak 800 ton sampah dari total sampah di Kota Pekanbaru produksi mencapai 1.000 ton setiap harinya. Sekretaris Dinas Lingkungan Hidup dan Kebersihan (DLHK) Kota Pekanbaru sangat berharap bila ada pihak lain yang menawarkan jasa pengolahan sampah. ${ }^{7}$

Pengelolaan sampah di Kota Pekanbaru masih menggunakan sistem kumpul angkut yang berakhir di Tempat Pembuangan Akhir (TPA) dengan menggunakan sistem kumpul angkut ini seberapapun besar TPA tetap akan penuh dan kembali akan membuka TPA baru.

Upaya-upaya cerdas, efisien dan terprogram melalui pendauran ulang dan pemanfaatan kembali sampah atau yang sering disebut dengan Reduce, Reuse dan recycle merupakan caracara yang dilakukan dalam kegiatan pengurangan timbunan sampah baik oleh masyarakat maupun pemerintah. ${ }^{8}$

Devi sebagai staf advokasi kampanye WALHI Riau mengatakan sampah yang berkontribusi paling besar itu adalah plastik yang dihasilkan dari gaya hidup. Tidak terbiasa membawa goody bag sendiri dan juga tidak terbiasa membawa bekal air minum, itu salah satu hal kecil yang berpengaruh sangat besar terhadap produksi sampah ${ }^{9}$.

Pemerintah Kota Pekanbaru telah mengeluarkan kebijakan berupa Peraturan daerah Kota Pekanbaru Nomor 8 Tahun 2014 tentang Pengelolaan Sampah pada PasaL 14 yang membahas tentang pengurangan sampah pada ayat (2) dikatakan bahwa Pemerintah Daerah Wajib melakukan kegiatan sebagaimana dimaksud sebagai berikut :

a. Menetapkan target pengurangan sampah secara bertahap dalam jangka waktu tertentu

b. Memfasilitasi penerapan teknologi yang ramah lingkungan

c. Memfasilitasi penerapan label produk yang ramah lingkungan

d. Memfasilitasi kegiatan mengguna ulang dan mendaur ulang; dan

e. Memfasilitasi pemasaran produk-produk daur ulang

Dalam Peraturan Daerah Kota Pekanbaru Nomor 8 Tahun 2014 tentang Pengelolaan sampah ini sangat jelas disebutkan dalam Peraturan Daerah Kota Pekanbaru, Pemerintah Kota Pekanbaru wajib melakukan kegiatan pengurangan sampah rumah tangga dan sampah sejenis sampah rumah tangga.

Masih banyak lokasi ilegal yang menjadi tempat penumpukan dan pembuangan sampah yang menghilangkan kesan indah dari kota pekanbaru. Pada tahun 2020 ini Pemerintah Kota Pekanbaru disarankan untuk melakukan evaluasi dari kerja sama dalam hal pengelola sampah yang telah dilakukan dengan pihak ketiga, dikarenakan pengelolaan sampah yang dilakukan dengan dua perusahaan sekaligus, hasilnya jauh dari yang diharapkan ${ }^{10}$

7 CK3, 'Produksi Sampah Warga Pekanbaru Tembus 1.000 Ton Perhari', Cakaplah, 2019, p. https://www.cakaplah.com/berita/baca/43980/2019/10, diakses 21 Oktober 2020.

${ }^{8}$ Prisa Ambar Shentika, 'Pengelolaan Sampah Di Kota Probolinggo', JESP, Vol. 1 No. 1, (2016), hlm. 93.

9 Riyan Novitra, 'Pengelolaan Sampah Di Pekanbaru Disebut Belum Baik', Riauonline.Co.Id, 2019, p. https://www.riauonline.co.id/riau/kota-pekanbaru/r, diakses 21 Oktober 2020.

10 'Masalah Sampah Harus Jadi Prioritas 2020', Riau Pos.Co, 2020, https://riaupos.jawapos.com/pekanbaru/03/01/2020/2, diakses 21 Oktober 2020. 
Dengan telah dikeluarkannya Peraturan Daerah Kota Pekanbaru Nomor 8 Tahun 2014 tentang Pengelolan Sampah, hal ini menjadi dasar hukum dalam hal penerapan pengelolaan sampah, terutama dalam hal kewajiban bagi Pemerintah Kota Pekanbaru untuk dapat melakukan kegiatan pengurangan sampah rumah tangga dan sampah sejenis sampah rumah tangga. Berdasarka fakta yang terjadi ditengah masyarakat bahwasanya masih terjadi penumpukan sampah yang tidak terkelola dengan baik yang meghilangkan kesan indah Kota Pekanbaru. Dengan masih adanya permasalahan ditengah masyarakat mengenai sampah namun disatu sisi sudah adanya peraturan yang mengatur mengenai hal tersebut, hal ini yang menjadi ketertarikan bagi penulis untuk dapat melihat problematika apakah yang terjadi yang menyebabkan pengelolaan sampah di Kota Pekanbarubelum dapat teratasi dengan baik.

\section{METODE PENELITIAN}

Penelitian ini terkategori penelitian hukum Sosiologis atau empiris dimana hukum dikonsepkan sebagai pranata sosial dan dikaitkan dengan variabel-variabel lainnya secara riil. ${ }^{11}$ Hukum sosiologis berguna untuk mengetahui proses penegakan hukum dan bagaimana dilaksanakannya hukum tersebut. ${ }^{12}$ Penelitian hukum empris menggunakan studi kasus hukum empiris yang berupa prilaku hukum didalam masyarakat. ${ }^{13}$ Sumber data yang digunakan dalam penelitian hukum empris adalah hasil observasi di lokasi penelitian. ${ }^{14}$ Pada pendekatan normatif di penelitian ini sumber data yang digunakan adalah data kepustakaan. Adapun yang akan menjadi sumber penelitian adalah melihat apa yang menjadi problematika hukum pengelolaan sampah di Kota Pekanbaru.

\section{HASIL DAN PEMBAHASAN}

Terbitnya Peraturan Daerah Kota Pekanbaru Nomor 8 Tahun 2014 tentang Pengelolan Sampah merupakan bentuk kepedulian dan tanggung jawab Pemerintah Kota Pekanbaru terhadap masyarakatnya. Sangat disayangkan sampai saat ini harapan dari pemerintah dalam terwujudnya Kota pekanbaru yang terbebas dari sampah masih sangat jauh dari harapan. Masih sangat beragam permasalahan yang dihadapi Pemerintah Kota Pekanbaru dalam usaha penyelesaian permasalahan sampah yang selalu menumpuk disana sini yang tentunya sangat mengganggu bagi masyarakat Kota Pekanbaru pada khususnya.

Telah dilakukan observasi terhadap objek penelitian dengan melakukan pengamatan langsung terhadap pihak terkait di bidang pengelolaan sampah.

Peraturan Daerah Kota Pekanbaru Nomor 8 Tahun 2014 tentang Pengelolaan Sampah mewajibkan untuk melakukan pengelolaan sampah rumah tangga dan sampah sejenis rumah tangga. Kasi Trantib Kecamatan Pekanbaru Kota mengungkapkan bahwasanya Peraturan Daerah Kota Pekanbaru Nomor 8 Tahun 2014 tentang Pengelolaan Sampah ialah bertujuan untuk

11 Amiruddin dan Zainal Asikin, 'Pengantar Metode Penelitian Hukum (edisi revisi)', Raja Grafindo Persada,(Jakarta), 2016, hlm. 115.

${ }^{12}$ Ibid. hlm. 134.

${ }^{13}$ Suteki dan Galang Taufani, 'Metodologi Penelitian Hukum (filsafat, Teori dan Praktik)', Raja Grafindo Persada,(Jakarta), 2018, hlm. 175.

${ }^{14}$ Ibid. 
menertibkan dan sebagai pedoman bagi masyarakat untuk keramahan lingkungan di Kota Pekanbaru. ${ }^{15}$

Ketua DPRD Kota Pekanbaru mengatakan bahwasanya pemerintah gagal jika dibandingkan dengan Perda itu sendiri artinya apa yang menjadi maksud dan tujuan dari Perda tersebut tidak berjalan semestinya di masyarakat. ${ }^{16}$

Bank Sampah adalah suatu tempat pengumpulan sampah yang sudah dipilah-pilah berdasrkan sampah organik dan sampah anorganik. ${ }^{17}$ Bank sampah adalah institusi lokal dimana kekuasaannya tidaklah besar. ${ }^{18}$

Bank sampah merupakan salah satu upaya dalam mengatasi persoalan penimbunan sampah. Bank sampah akan melakukan program pemanfaatan sampah dengan cara mengurangi penggunaan barang yang dapat menghasilkan sampah, usaha dalam menggunakan kembali sampah dan mengolah sampah menjadi barang-barang yang dapat dimanfaatkan, yang biasa disebut dengan $3 \mathrm{R}$ reduce, reuse dan recycle.

Bagian Operasional Bank Sampah The Gade (Clean \& Gold), sangat setuju sekali, dimana sudah semestinya sampah yang dihasilkan oleh aktifitas rumah tangga, masyarakat, dan sejenisnya melalui proses pengelolaan ditingkat atau lapisan awal baik pemerintah, dunia usaha ataupun masyarakat luas umumnya. Adapaun pengelolaan sampah yang paling mudah dan memungkinkan dilakukan oleh semua orang adalah dengan proses pemilahan atau memilah sampah. Dimana salah satu cara mengurangi tumpukan sampah yakni menjalankan program $3 \mathrm{R}$. bank sampah adalah merupakan salah satu wadah yang dapat menjalankan 3R tersebut dengan baik. $^{19}$

Kabid Pengelolaan Sampah Dinas Kebersihan dan Lingkungan Hidup Kota Pekanbaru mengemukakan bahwasanya dalam Perda sudah dibunyikan mulai pukul 19.00 sampai dengan pukul 05.00 WIB adalah waktu untuk membuang sampah pada tempat yang sudah tersedia. Kita melakukan pendekatan kepada masyarakat dengan sosialisasi, baik secara langsung maupun tidak lansung. Secara langsung dilakukan dengan mengajak setiap kelurahan dan RT/RW disetiap kelurahan untuk datang ke kantor camat. Secara tidak langsung dilakukan dengan sosialisasi melalui web dinas, media sosial, dan televisi. Sampah-sampah tersebut ditelusuri untuk selanjutnya di letakkan di TPS, bagi mereka yang tidak mau membuang sampahnya atau tidak mau memilahnya sendiri, bisa dialihkan dengan pembayaran retribusi, nanti sampah diagntung saja, dan tukang sampah datang untuk mengambil. ${ }^{20}$

\footnotetext{
${ }^{15}$ Wawancara dengan R. Yupi Swansyah selaku Kasi Trantib Kecamatan Pekanbaru Kota tanggal 08 Februari 2021, pukul 08.45 WIB di Kantor Kecamatan Pekanbaru Kota.

${ }^{16}$ Wawancara dengan Sigit Suwono, S.T., selaku Ketua Komisi IV DPRD Kota Pekanbaru tanggal 24 Februari 2021, pukul 10.30 WIB di Halaman Kantor Kecamatan Bukit Raya.

${ }^{17}$ Op. Cit., hlm. 2.

18 Rustam Effendi, Boy Syamsul Bakhri dan Yuhermi Okta Mursi, 'Pengaruh Peranan Bank Sampah Dalang Collection Terhadap Kesejahteraan Karyawan Perspektif Ekonomi Syariah', Jurnal Al Hikmah, Vol. 15 No. 2, (2018), hlm. 47.

19 Wawancara dengan Edi Rahmat selaku Bagian Operasional Bank Sampah The Gade (Clean \& Gold) Kota Pekanbaru tanggal 11 Februari 2021, pukul 15.28 WIB by Daring.

${ }^{20}$ Wawancara dengan Novan Serwanto selaku Kepala Bidang Pengelolaan Sampah Kota Pekanbaru tanggal 24 Februari 2021, pukul 10.37 WIB di Halaman Kantor Kecamatan Bukit Raya.
} 
Kasi Trantib Camat Bukit Raya, menjelaskan tentang sampah-sampah yang menumpuk itu, perlu adanya lelang yang nantinya siapa saja yang menang dalam lelang tersebut merekalah yang akan bekerja sama dengan Pemerintah untuk mengurangi penimbunan sampah. Hal ini sudah diinstruksikan. Disini ada juga namanya swakelola, yaitu pihak ketiga yang bekerja sama dengan lurah setempat. Masyarakat juga telah kita himbau untuk memanfaatkan sampah-sampah tersebut menjadi bernilai. Baik masyarakat maupun pegawai yang ada di kantor camat bukit raya, memilah sampah untuk nantinya dijemput oleh Bank Sampah. Sampah yang dipilah adalah sampah kering yang dikelola oleh bank sampah dan sekelompok masyarakat yang tergabung di dalamnya. Selanjutnya ada sampah basah, inilah yang akan dikelola oleh swakelola.

Adanya bank sampah merupakan salah satu cara sebagai upaya dalam menyelesaikan persoalan sampah sebagai perwujudan dari apa yang menjadi tujuan di terbitkannya Peraturan Daerah Kota Pekanbaru Nomor 8 Tahun 2014 tentang Pengelolaan Sampah. Bukanlah suatu hal yang mudah dalam menerapkan suatu kebijakan. Peran aktif masyarakat dalam bentuk partisipasi yang nyata sangat-sangat diharapkan guna tercapainya tujuan dari suatu kebikan yang ditetapkan.

Mengingat pentingnya partisipasi dalam pembangunan, tentunya menjadi mutlak bahwasanya segala sesuatu yang berhubungan dengan pengambilan kebijakan oleh pemerintah tentunya harus melibatkan masyarakat. ${ }^{21}$

Kendala yang dihadapi dalam upaya pengurangan sampah di Kota Pekanbaru merupakan hal yang sangat mendasar yang ditanyakan kepada para responden. Ketua Komisi IV DPRD Kota Pekanbaru mengatakan sampah di TPA tidak dikelola dengan baik sehingga kebanyakan sampah hanya menumpuk begitu saja serta masih kurangnya peranan bank sampah dalam upaya pengurangan sampah. ${ }^{22}$

Kabid Pengelolaan Sampah Dinas Kebersihan dan Lingkungan Hidup Kota Pekanbaru, dalam perda sudah dibunyikan mulai pukul 19.00 sampai dengan pukul 05.00 WIB adalah waktu untuk membuang sampah namun tidak disiplinnya masyarakat dalam mematuhi jadwal yang sudah ditetapkan menjadi salah satu masalah yang mengakibatkan terjadinya penumpukan sampah yang terus menerus. ${ }^{23}$

Kesadaran hukum merupakan kesadaran dari diri sendiri tanpa adanya tekanan ataupun paksaan serta perintah dari luar untuk patuh pada hukum yang berlaku. Bila kesadaran hukum berjalan di masyarakat sudah semestinya hukum tidak perlu menjatuhkan sanksi. ${ }^{24}$

Direktur Bank Sampah Mitra Karya (di kelola RT 02/RW 01, Kel. Tampan, Kec. Payung Sekaki) menyampaikan kendala yang dihadapi adanya sebagaian warga yang tidak mau datang ke Bank Sampah untuk mengantarkan sampahnya. ${ }^{25}$

${ }^{21}$ Op. Cit., hlm. 131.

${ }^{22}$ Wawancara dengan Sigit Suwono, S.T., selaku Ketua Komisi IV DPRD Kota Pekanbaru tanggal 24 Februari 2021, pukul 10.30 WIB di Halaman Kantor Kecamatan Bukit Raya.

${ }^{23}$ Wawancara dengan Novan Serwanto selaku Kepala Bidang Pengelolaan Sampah Kota Pekanbaru tanggal 24 Februari 2021, pukul 11.00 WIB di Halaman Kantor Kecamatan Bukit Raya.

${ }^{24}$ Ellya Rosana, 'Kepatuhan Hukum sebagai Wujud Kesadaran Hukum Masyarakat', Jurnal TAPIs, Vol. 10 No. 1, hlm. 3.

${ }^{25}$ Wawancara dengan Suko Herunomo selaku Ketua RT 02 Kelurahan Tampan, Kecamatan Payung Sekaki tanggal 06 Februari 2021, pukul 09.07 WIB di Tempat Pengumpulan Bank Sampah. 
Bagian Operasional Bank Sampah The Gade (Clean \& Gold) mengungkapkan kurangnya perhatian atau kepedulian Pemerintah atau intansi terkait dalam mensupport jalannya aktivitas Bank Sampah baik itu berupa Anggaran (dana Operasional) maupun berupa regulasi atau aturanaturan yang dapat menjamin keberlangsungan operasional Bank Sampah. ${ }^{26}$

Ketua Bank Sampah Berkah Abadi Limbungan, kendalanya ada pada keuangan. Dikarenakan sejauh ini masih ada dana pribadi yang terpakai dalam menjalankan bank sampah ini. $^{27}$

PJ BSMK Binaan Dalang Collection mengatakan bahwa alat-alat pengelolaan yang minim, lahan yang terbatas namun yang sangat menjadi kendala adalah alat transportasi sehingga kami merasa kesulitan untuk mengangkut sampah.. ${ }^{28}$

Kasi PPN Camat Rumbai Barat, mengatakan sulitnya mengubah mindset masyarakat untuk memilah sampah organik dan anorganik. ${ }^{29}$

Kabid Pengelolaan Sampah Dinas Kebersihan dan Lingkungan Hidup Kota Pekanbaru menyebutkan sanksi yang diberikan kepada masyarakat yang membuang sampah tidak sesuai dengan waktu yang telah di jadwalkan tidak menjadi efek jera bagi masyarakat. Kendala selanjutnya, terkait armada dimana kita kekurangan armada dalam memenuhi tuntutan 15 kecamatan yang ada di Kota Pekanbaru. Untuk saat ini kita memerlukan armada yang lebih besar dengan jumlah roda 6 . Normalnya armada hanya ada 23, terdiri dari 16 coldiesel dan 6 L300 dan sekarang ada 45. Setiap armada ada dua shift, shift pagi dan siang. Jika armada di pagi hari rusak, maka untuk jam siang akan terkendala, hal inilah yang menyebankan terjadinya penumpukan sampah. Terlebih lagi untuk saat ini, banyak armada yang kondisinya sudah tidak memungkinkan untuk beroperasi. Lalu kendala lain datang dari pihak tertentu yang menghalangi untuk dibangunnya suatu TPS dengan berbagai alasan tidak mau ribet, terganggu akan baunya. dan jika ingin membuat TPS ini, haruslah tanah Hibah. ${ }^{30}$

\section{PENUTUP}

Peningkatan jumlah penduduk tentunya sejalan dengan peningkatan sampah yang dihasilkan, namun bank sampah yang ada di Kota Pekanbaru belum berjalan secara maksimal.

Sulitnya merubah kebiasaan masyarakat untuk dapat membuang sampah sesuai dengan jadwal yang telah ditetapka dan juga sulitnya membisakan masyarakat untuk dapat memilah sampah organik dan anorganik.

\footnotetext{
${ }^{26}$ Wawancara dengan Edi Rahmat selaku Bagian Operasional The Gade (Clean \& Gold) Kota Pekanbaru tanggal 11 Februari 2021, pukul 15.28 WIB by Daring.

${ }^{27}$ Wawancara dengan Ibnu Hajar selaku Ketua Bank Sampah Berkah Abadi Limbungan, tanggal 15 Februari 2021, pukul 08.34 WIB di Kantor Bank Sampah Berkah Abadi Limbungan

${ }^{28}$ Wawancara dengan Syukri selaku PJ BSMK Binaan Dalang Collection tanggal 10 Februari 2021, pukul 13. 45 WIB di Kantor Bank Sampah Dalang Collection.

${ }^{29}$ Wawancara dengan Gusti Henni Purwati selaku Kasi PPM Camat Rumbai Barat tanggal 10 Februari 2021, Pukul 09.29 WIB di Kantor Camat Rumbai Barat.

30 Wawancara dengan Novan Serwanto selaku Kepala Bidang Pengelolaan Sampah Kota Pekanbaru tanggal 24 Februari 2021, pukul 10.47 WIB di Halaman Kantor Kecamatan Bukit Raya.
} 
Kurangnya armada pengangkut sampah dan juga armada yang ada sudah tidak layak pakai. Sulitnya lahan dalam pembangunan TPS, serta kurangnya perhatian / kepedulian pemerintah terhadap jalannya aktivitas bank sampah, Pemerintah Kota pekanbaru belum sepenuhnya memberikan dukungan dalam hal pengelolaan sampah terutama terkait dalam hal keuangan.

Pemerintah dan bank sampah senantiasa tiada henti untuk terus mensosialisasi terkait Peraturan Daerah Kota Pekanbaru Nomor 8 Tahun 2014 tentang Pengelolan Sampah secara berkala kepada masyarakat.

Agar pemerintah lebih memperhatikan bank sampah terutama masalah pendanaan dan pemasaran barang hasil produksi dari bank sampah.

Armada pengangkut sampah harus ditambah dan mengganti armada yang sudah tidak layak pakai.

\section{DAFTAR PUSTAKA}

Amiruddin dan Zainal Asikin, 'Pengantar Metode Penelitian Hukum (edisi revisi)', Raja Grafindo Persada,(Jakarta), 2016.

CK3, 'Produksi Sampah Warga Pekanbaru Tembus 1.000 Ton Perhari', Cakaplah, 2019, p. https://www.cakaplah.com/berita/baca/43980/2019/10, diakses 21 Oktober 2020.

Dilva Ramdhan, 'Kebijakan Daerah Pemerintah Kota Pekanbaru Dalam Pengelolaan Sampah Denga Konsep 3r Tahun 2017', JOM FISIP, Vol.6 No.11, (2019).

Ellya Rosana, 'Kepatuhan Hukum sebagai Wujud Kesadaran Hukum Masyarakat', Jurnal TAPIs, Vol. 10 No. 1, hlm. 3

Roza Linda, 'Pemberdayaan Ekonomi Kreatif Melalui Daur Ulang Sampah Plastik (studi kasus bank sampah berlian kelurahan tangkerang labuai)', Jurnal Al-Iqtishad, Vol. 1 No.12, (2016).

Irienda Rielasari, 'Pengelolaan Sampah Kota Pekanbaru', JOM FISIP, Vol. 5 No.1, (2018).

Yudi Anugrah Purwadi, 'Implementasi Peraturan Daerah Kota Pekanbaru Nomor 08 Tahun 2014 Tentang Pengelolaan Sampah (Studi Tentang Masyarakat Peduli Sampah)', JOM FISIP, Vol. 4 No. 2, (2017).

Hadnan Bachtiar, Imam Hanafi dan Mochamad Rozikin, 'Pengembangan Bank Sampah Sebagai Bentuk Partisipasi Masyarakat Dalam Pengolahan Sampah (studi pada koperasi bank sampah malang) ', Jurnal Administrasi Publik (JAP), Vol. 3 No.1.

Prisa Ambar Shentika, 'Pengelolaan Sampah Di Kota Probolinggo', JESP, Vol. 1 No. 1, (2016).

Rustam Effendi, Boy Syamsul Bakhri dan Yuhermi Okta Mursi, 'Pengaruh Peranan Bank Sampah Dalang Collection Terhadap Kesejahteraan Karyawan Perspektif Ekonomi Syariah', Jurnal Al Hikmah, Vol. 15 No. 2, (2018).

Imah Luluk Kusminah, 'Penyuluhan 4R (Reduce, Reuse, Recycle, Replace) Dan Kegunan Bank Sampah Sebagai Langkah Menciptakan Lingkungan Yang Bersih Dan Ekonomis Di Desa Mojowuku Kabupaten Gresik’, Jurnal Pengabdian Masyarakat LPPM Untag Surabaya, Vol. 3 No.1, (2018). 
Suteki dan Galang Taufani, 'Metodologi Penelitian Hukum (filsafat, Teori dan Praktik)', Raja Grafindo Persada,(Jakarta), 2018.

Riyan Novitra, 'Pengelolaan Sampah Di Pekanbaru Disebut Belum Baik', Riauonline.Co.Id, 2019, p. https://www.riauonline.co.id/riau/kota-pekanbaru/r, diakses 21 Oktober 2020.

Masalah Sampah Harus Jadi Prioritas 2020', Riau Pos.Co, 2020, https://riaupos.jawapos.com/pekanbaru/03/01/2020/2, diakses 21 Oktober 2020. 